\title{
An Evaluation of Factors Predisposing Building Elements to Variation in Nigeria
}

\author{
Babatunde, S.O. ${ }^{1}$, Babalola, M.O.. ${ }^{1}$ Jagboro, G.O' ${ }^{1}$ and Opawole, A. ${ }^{1}$
}

\begin{abstract}
The construction industry has been consistently criticized for poor performance in attaining clients' requirements. The study, thus, assessed the factors predisposing building elements to variation with a view to providing cost-design information that enhance construction project delivery, that is, on-time completion of project within budget. The building elements considered in this study include substructure, frame, upper floors, and roof. Data were collected using well-structured questionnaires administered on professionals in consulting firms, contracting firms, and client organizations in Lagos metropolis. Data analysis was done using descriptive and inferential statistics. The results of the analysis revealed nine factors through factor analysis that predispose substructure to variation, seven factors predispose frame, six factors predispose upper floors, and seven factors predispose roofs to variation during construction process in Nigeria.
\end{abstract}

Keywords: Building elements, construction industry, performance, variations.

\section{Introduction}

Construction project is usually considered as successful if it is completed on time, within budget and to the level of quality standard specified by the client. However, severe criticisms of the construction industry are generated when projects take far longer than planned [1]. The construction process is unique in its sense in terms of planning, finance, and labour requirement. Harris and McCaffer [2] described construction process as an inherently uncertain activity. This uncertainty can be easily identified as a result of the product and nature of the construction industry. Various factors such as design, tendering process, soil and site conditions, sector share of government policies, weather, and user's requirements are all variables that affect construction project delivery. Arising out of these uncertainties is the construction contract phenomenon of variation.

The construction industry, as common with most industries, is beset with problems of efficiency and productivity. These problems are perhaps much greater in the construction industry than any other industry due to the complex nature of the industry and the unique characteristics of its end product [3]. Akinsola et al [4] stated that it is evident today, more than ever, that claims and disputes in construction have become endemic especially those caused by variations.

${ }^{1}$ Department of Quantity Surveying, Obafemi Awolowo University, Mle-Ife, NIGERIA.

Correspondence Email: sholly_intl@yahoo.com

Note: Discussion is expected before June, $1^{\text {st }} 2013$, and will be published in the "Civil Engineering Dimension" volume 15, number 2, September 2013.

Received 25 September 2011; revised 18 Julu 2012; accepted 21 November 2012
Ssegawa et al [5] asserted that building project is liable to variations due to changes of mind on the part of the clients, the consultants, or unforeseen problems raised by the main contractor or subcontractor. Variations, therefore, occur for a number of reasons ranging from finance, design, aesthetic, geotechnical, geological, weather conditions to feasibility of construction. Variations are inevitable in any construction project [6]. Needs of the clients may also change in the course of design or construction, market conditions may impose changes to the parameters of the project, and technological developments may alter the design and the choice of the engineer [7].

Thus, in the face of inevitable occurrence of variations in construction projects, cost-design information to designers for elemental assessment of a building at design stage is highly imperative to have in-depth knowledge of elements with higher proneness to variation and the elements that require specific attention. The study identified and assessed the factors that predispose building elements to variation with a view to designing a proactive cost control system on construction projects.

\section{Factors Predisposing Building Elements to Variations}

A building element is a component of the building that fulfils specific function(s) irrespective of its design, construction or specification. Examples are substructure, superstructure-frame, upper floors, roofs, stairs, to mention but few. Robert and Harrold [8] defines building elements as components common to most buildings that usually perform a given func- 
tion, regardless of the design, specification, construction method, or materials used. Element classification ensures consistency in the economic evaluation of building projects over time and from project to project. It enhances project management and reporting at all stages of the building life cycle: planning, programming, design, construction, operations, and disposal [9].

Variation in quality and quantity of building elements do not just happen. Some factors are often responsible for susceptibility of the elements and the factors affect each element differently. The predisposing factors can be grouped into four viz: client related factors, consultant related factors, contractor related factors, and natural related factors [10]. The predisposing factors and other causes of variation orders on construction projects have been identified by many researchers [11-18]. These factors need to be accurately assessed and determined during the planning stage of building elements design so as to minimize the effects of variation on the various building elements.

Client related factors are factors that are initiated by the client. In some cases, the client directly initiates variations on building elements or the variations are required because the client fails to fulfill certain requirements for carrying out the project. These may include change of plans or scope by client, change of schedule by client, replacement of materials or procedures, impediment in prompt decision making process, nature of client, and change in specifications by client, to mention but a few.

Consultant related factors are factors that are initiated by the consultant. In some cases, the consultant directly initiates variations among building elements or the variations are required because the consultant fails to fulfill certain requirements for carrying out the project. Aibinu and Jagboro [19] asserted that architect has the responsibility not only to a good design and completion and erection but also to both economic initial capital cost and subsequent maintenance cost. Sometimes the architect is unable to merge the wide and unrealistic desires of the clients with the client's financial capability. These include change in design by consultant, errors and omissions in design, conflicts between contract documents, inadequate scope of work for contractor, inadequate working drawing details, consultant's lack of judgment and experience, and ambiguous design details, to mention but a few. Contractor related factors are the factors initiated by the contractors on construction sites. For example, the contractor may suggest variations among building elements during construction processes or the variations may be required because the contractor fails to fulfill certain requirements for carrying out the project. These include lack of contractor's involvement in design, contractor's desired profitability, contractor's lack of judgment and experience, and contractor's lack of required data. The natural related factors prone building elements to variations during construction process, these factors are not directly related to the participants. These include weather conditions, unforeseen problems, and force majeure.

\section{Data and Method}

Data for the study were collected through the use of well-structured questionnaire administered on professionals comprising architects, builders, civil engineers, and quantity surveyors in consulting firms, contracting firms, and client organizations within the built environment in Lagos metropolis. The data were limited to educational building projects awarded and completed within a ten-year period from 2001 to 2010. Educational buildings were chosen because there are always proper contract documentations and all the professionals within the built environment are often involved which led to the award of contract to the contractor within a time frame. Also, this period is considered to have experienced the same economic climate in Nigeria [20]. The study area was restricted to Lagos metropolis in Southwestern Nigeria for its feature of highest concentration of building projects in Nigeria [21]. Also, 60-65\% of head offices of both consulting and contracting firms are located in this region. The study adopted equal selections from target population: 50 consulting firms, 50 contracting firms, and 50 client organizations in the study area. This gives a total sample size of 150 . Thus, 150 copies of questionnaire were purposively administered on professionals in the selected firms. A total of 101 copies representing 67.33\% were collected and found suitable for the analysis. The data collected were presented in tables and analyzed using factor analysis and Multiple Comparison Test via Tukey (Honestly Significant Difference-HSD) test $[22,23]$. Tukey HSD test was used to determine significance difference among the identified factors that predispose building elements to variations.

Respondents were asked to rate the factors that predispose each element to variation on a scale of 1-5 with 1 representing very low and 5 very high. The five-point scale ( 1 to 5 ) was transformed into relative significance index for each factor by using the numerical scores. Relative significance index (RSI) was employed for two purposes, i.e. ranking and determination of significance of different factors of the collected data. The RSI values were obtained for each building elements on how the elements are 
susceptible to variations from the clients', consultants' and contractors' perspectives. The average RSI values calculated for each building element served as likelihood of proneness of each building elements to variation.

The RSI was determined using the formula:

$$
R S I=A /(B \times C), 0 \leq R S I \leq 1
$$

In which $\mathrm{A}$ is the total score; $\mathrm{B}$ the highest response; and $\mathrm{C}$ the total number of responses. Factor analysis was carried out on the data obtained using Statistical Package for Social Sciences (SPSS) [24]. Factor analysis was used to reduce the variables of the factors to few conceptually meaningful and relatively independent factors, each of which represents some combination of original variables by factor extraction. The resulting score of each of the items making up a factor were aggregated to build a measure of that factor. The resulting factor scores were then subjected to cluster analysis to group the respondents into the prevalent factor chosen by each respondent. A test of difference was conducted on the rating of factors causing each element to variation on the basis of the factors identified using Multiple Comparison Analysis via Tukey HSD Test to identify the critical factors predisposing the elements to variation.

\section{Data Analysis}

The percentage representation of respondents showed that $68 \%$ of contracting, $80 \%$ of consulting firms, and $54 \%$ of client organizations responded. The detailed breakdown of designations of respondents from contracting, consulting, and client organizations revealed that $25.74 \%$ were architects, $19.80 \%$ were builders, $29.70 \%$ were civil engineers and $24.75 \%$ were quantity surveyors. The highest academic qualification of respondents indicated that 5.94\% obtained National Diploma, 36.63\% obtained Higher National Diploma, 9.90\% obtained Postgraduate Diploma, 40.60\% obtained Bachelor of Science and $6.93 \%$ obtained Master of Science. The average of the projects handled by respondents from 2001-2010 were eight projects and the average years of professional experience of respondents was approximately 11 years. It can be deduced that the respondents were suitable and have acquired adequate experience in the Nigerian construction industry. Based on this premise, the information supplied by these respondents was reliable and dependable.

Table 1 revealed nine extracted factors through factor analysis that predispose substructure to variation. The first factor from the factor analysis result, which is interpreted as consultant's related factor, comprises lack of consultant's knowledge of available material and equipment, lack of coordination, ambiguous design details, consultant's lack of required data, change in specification by consultant, inadequate working drawing details, change in design by consultant, and errors and omissions in design. The second factor is named as contractor's related factor. These include, lack of contractor's involvement in design, unavailability of equipment by contractors, and contractor's desired profitability. The third factor identified by factor analysis interpreted as client's related factor comprises change of scope by client, client's financial constraint, change of specification by client, and change of schedule by client. The fourth factor was identified as workmanship related factor. The items loaded under this factor include defective workmanship and shortage of skilled manpower. The fifth factor is interpreted as government related factor. The items loaded under this factor include legislation and non

Table 1. Rotated Component Matrix of Factors Predispose Substructure to Variation

\begin{tabular}{ll}
\hline Items & \\
\hline Items of Component 1: & \\
Lack of consultant's knowledge of available & 0.832 \\
$\quad$ materials and equipment & 0.782 \\
Lack of coordination & 0.759 \\
Ambiguous design details & 0.744 \\
Consultant's lack of required data & 0.742 \\
Change in specification by consultant & 0.737 \\
Inadequate working drawing details & 0.704 \\
Change in design by consultant & 0.669 \\
Errors and omissions in design & 0.580 \\
Lack of strategic planning & 0.575 \\
Inadequate scope of work for contractor & 0.440 \\
Complex design & \\
\hline Items of Component 2: & 0.878 \\
Lack of contractor's involvement in design & 0.695 \\
Unavailability of equipment & 0.677 \\
Contractor's desired profitability & \\
\hline Items of Component 3: & 0.855 \\
Change of scope by client & \\
Client's financial constraint & \\
Change of specification by client & 0.800 \\
Change of schedule by client & 0.725 \\
\hline Items of Component 4: & 0.585 \\
Defective workmanship & \\
Shortage of skilled manpower & 0.565 \\
\hline Items of Component 5: & 0.719 \\
Non compliance of design with government & \\
$\quad$ regulations & 0.724 \\
Legislation & 0.598 \\
\hline Items of Component 6: & \\
Change in economic conditions & \\
\hline Items Component 7: & \\
Technological change & 0.595 \\
Complex design and technology & \\
\hline Items Component 8: & \\
Safety considerations & \\
Security reasons & \\
\hline Items of Component 9: & \\
Unfavorable site condition & \\
Force majeure & \\
\hline
\end{tabular}


compliance of design with government regulations. The sixth factor is named economic related factor comprising change in economic conditions. The seventh factor identified as technological related factor comprises technological change, and complex design and technology. The eighth factor is interpreted as safety related factor and includes safety considerations and security reasons. The ninth factor is identified as natural related factor comprises unfavorable site condition and force majeure.

Table 2 revealed the seven reduced factors through factor analysis that predispose frame to variation. The first factor from factor analysis result which is interpreted as consultant's related factor comprises change in specification by consultant, inadequate working drawing details, change in design by consultant, lack of consultant's knowledge of available material and equipment, consultant's lack of requireed data, ambiguous design details, and lack of coordination. The second factor identified technological related factor includes complex design and technology, technological change, and design complexity. The third factor named as workmanship's related factor comprises shortage of skilled manpower,

Table 2. Rotated Component Matrix of Factors Predisposing Frame to Variation

\begin{tabular}{ll}
\hline Items & \\
\hline Items of Component 1: & \\
Change in specification by consultant & 0.871 \\
Inadequate working drawing details & 0.804 \\
Change in design by consultant & 0.571 \\
Lack of consultant's knowledge of available & \\
$\quad \quad \quad$ materials and equipment & 0.531 \\
Consultant's lack of required data & 0.477 \\
Ambiguous design details & 0.454 \\
Lack of coordination & 0.451 \\
\hline Items of Component 2: & \\
Complex design and technology & 0.826 \\
Technological change & 0.819 \\
Design complexity & 0.804 \\
\hline Items of Component 3: & \\
Shortage of skilled manpower & 0.797 \\
Defective workmanship & 0.661 \\
Lack of supervision & 0.545 \\
\hline Items of Component 4: & \\
Safety considerations & 0.831 \\
Security reasons & 0.701 \\
\hline Items of Component 5: & \\
Change in economic conditions & 0.702 \\
Financial constraint & 0.626 \\
\hline Items of Component 6: & 0.472 \\
Unfavorable site condition & 0.599 \\
\hline Force majeure & \\
\hline Items of Component 7: & \\
Non compliance of design with government & \\
Legislations & \\
\hline
\end{tabular}

defective workmanship, and lack of supervision. The fourth factor identified as safety related factor includes safety considerations and security reasons. The fifth factor named as economic related factor comprises change in economic conditions, and financial constraint. The sixth factor is identified as natural related factor including unfavorable site conditions and force majeure. The seventh factor named as government's related factor comprises non compliance of design with government regulation and legislations.

Table 3 revealed the six extracted factors through factor analysis that predispose upper floors to variation. The first factor which is interpreted as economic related factor comprises financial constraint, and change in economic condition. The second factor named as contractor's related factor includes unavailability of equipment, contractor's desired profitability, lack of contractor's involvement in design, inadequate working details, and inadequate knowledge of work for contractor. The third factor is identified as consultant's related factor comprises lack of coordination, ambiguous design details, consultants' lack of required data, change in specification by consultant, inadequate working drawing details, and change in design by consultant. The

Table 3. Rotated Component Matrix of Factors Predispose Upper Floors to Variation

\begin{tabular}{ll}
\hline Items & \\
\hline Items of Component 1: & 0.688 \\
Financial constraint & 0.676 \\
\hline Change in economic conditions & \\
\hline Items of Component 2: & 0.471 \\
Unavailability of equipment & 0.473 \\
Contractor's desired profitability & 0.448 \\
Lack of contractor's involvement in design & 0.832 \\
Inadequate working details & 0.780 \\
\hline Inadequate knowledge of work for contractor & \\
\hline Items of Component 3: & 0.810 \\
Lack of coordination & 0.708 \\
Ambiguous design details & 0.705 \\
Consultant's lack of required data & 0.615 \\
Change in specification by consultant & 0.579 \\
Inadequate working drawing details & 0.430 \\
Change in design by consultant & \\
\hline Items of Component 4: & 0.636 \\
Defective workmanship & 0.583 \\
\hline Shortage of skilled manpower & \\
\hline Items of Component 5: & 0.767 \\
Change of scope by client & 0.708 \\
Change of schedule by client & 0.698 \\
Change of specification by client & \\
\hline Items of Component 6: & 0.690 \\
Complex design and technology & 0.527 \\
Technological changes & 0.506 \\
\hline Design complexity &
\end{tabular}


fourth factor identified as workmanship's related factor includes defective workmanship and shortage of skilled manpower. The fifth factor named as client's related factor comprises change of scope by client, change of schedule by client, and change of specification by client. The sixth factor identified as technological related factor includes complex design and technology, technological changes, and design complexity.

Table 4 showed the seven extracted factors through factor analysis that predispose roofs to variation. The first factor from factor interpreted as client's related factor comprises replacement of materials or procedures, impediment in prompt decision making process, change of schedule by client, nature of client, change of plan or scope by client. The second factor named economic related factor includes change in economic condition, and financial constraint. The third factor identified as consultant's related factor comprises inadequate working drawing details, lack of coordination, lack of consultant's knowledge of available materials and equipment, ambiguous design details, consultant's lack required data. The fourth factor is identified as technological factor including complex design and technology and techno-

Table 4. Rotated Component Matrix of Factors Predispose Roofs to Variation

\begin{tabular}{ll}
\hline Items & \\
\hline Items of Component 1: & 0.823 \\
Replacement of materials or procedures & 0.776 \\
Impediment in prompt decision making process & 0.741 \\
Change of schedule by client & 0.645 \\
Nature of client & 0.592 \\
Change of plan or scope by client & \\
\hline Items of Component 2: & 0.742 \\
Change in economic condition & 0.736 \\
Financial constraint & \\
Items of Component 3: & 0.741 \\
Inadequate working drawing details & 0.719 \\
Lack of coordination & 0.711 \\
Lack of consultant's knowledge of available & 0.701 \\
$\quad$ materials and equipment & 0.629 \\
\hline Ambiguous design details & \\
Consultant's lack required data & 0.753 \\
\hline Items of Component 4: & 0.749 \\
Complex design and technology & \\
Technological changes & 0.771 \\
\hline Items of Component 5: & 0.612 \\
Inadequate scope of work for contractor & 0.571 \\
\hline Lack of contractor's involvement in design & \\
Contractor's desired profitability & 0.670 \\
\hline Items of Component 6: & 0.567 \\
Non compliance of design with government & \\
$\quad$ regulations & \\
Legislations & \\
Items of Component 7: & \\
Defective workmanship & \\
\hline
\end{tabular}

logical changes. The fifth factor named as contractor's related factor comprises inadequate scope of work for contractor, lack of contractor's involvement in design, and contractor's desired profitability. The sixth factor identified as government's related factor includes non compliance of design with government regulations and legislations. The seventh factor named as workmanship's related factor comprises defective workmanship.

In order to identify the critical factors predisposing each of the elements to variation, the results obtained in Tables 1-4 were subjected to Multiple Comparison Analysis using Tukey HSD Test. This is presented in Table 5. The results showed that among the nine factors predisposing substructure to variation, the critical ones are technological related factor, workmanship related factor and economic related factor. Two factors, that are, consultant related factor and workmanship related factor, are critical factors causing variation in frame. On the other hand, three factors, that are, contractor's related factor, economic related factor, and workmanship related factor, are critical factors causing variation in upper floors and three factors which are economic related factor, client's related factor, and technological related factor are critical factors causing variation in roof. These results imply that designers (architects and engineers) should undertake comprehensive assessment of building elements with respect to availability of technological and manpower requirement at the design stage. Also, the consultants should ensure that designs are thorough and detailed at the design stage to facilitate adequate planning while clients should be adequately informed at design stage about the cost requirements of the elements and likely fluctuation that may occur during the project execution.

\section{Conclusion}

The study identified nine factors, that are, consultant's related factor, contractor's related factor, client's related factor, workmanship related factor, government related factor, economic related factor, technological related factor, safety related factor, and natural related factor, that predispose substructure to variation. The study also identified seven factors that predispose frame to variation as consultant's related factor, technological related factor, workmanship related factor, safety related factor, economic related factor, natural related factor, and government related factor. Six factors comprising economic related factor, contractor's related factor, consultant's related factor, workmanship related factor, client's related factor, and technological related factor were identified as predisposing upper floors to variation. Seven factors, that are, client's related factor, economic 
Table 5. Critical Factors Causing Variation in Each Building Element Extracted Using Tukey HSD Test

\begin{tabular}{|c|c|c|c|c|c|}
\hline $\begin{array}{l}\text { Building } \\
\text { Elements }\end{array}$ & Identified Factors & $\begin{array}{c}\text { Number } \\
\text { of Factors } \\
\text { Identified } \\
\end{array}$ & Critical Factors & $\begin{array}{l}\text { Non- Critical } \\
\text { Factors }\end{array}$ & $\begin{array}{c}\text { Remark/Recommen- } \\
\text { dation }\end{array}$ \\
\hline Substructure & $\begin{array}{l}\text { Consultant's related } \\
\text { factor, contractor's related } \\
\text { factor, client's related } \\
\text { factor, workmanship } \\
\text { related factor, } \\
\text { government related } \\
\text { factor, economic related } \\
\text { factor, technological } \\
\text { related factor, safety } \\
\text { related factor and natural } \\
\text { related factor. }\end{array}$ & 9 & $\begin{array}{l}\text { Technological } \\
\text { related factor, } \\
\text { workmanship } \\
\text { related factor and } \\
\text { economic related } \\
\text { factor. }\end{array}$ & $\begin{array}{l}\text { Safety related } \\
\text { factor and } \\
\text { consultant related } \\
\text { factor. }\end{array}$ & $\begin{array}{l}\text { The designers should } \\
\text { undertake comprehensive } \\
\text { feasibility assessment of the } \\
\text { element with respect to } \\
\text { availability of technological } \\
\text { and manpower requirement } \\
\text { of the element. }\end{array}$ \\
\hline Frame & $\begin{array}{l}\text { Consultant's related } \\
\text { factor, technological } \\
\text { related factor, } \\
\text { workmanship's related } \\
\text { factor, safety related } \\
\text { factor, economic related } \\
\text { factor, natural related } \\
\text { factor, government's } \\
\text { related factor. }\end{array}$ & 7 & $\begin{array}{l}\text { Consultant related } \\
\text { factor and } \\
\text { workmanship } \\
\text { related factor. }\end{array}$ & $\begin{array}{l}\text { Natural related } \\
\text { factor, safety } \\
\text { related factor and } \\
\text { government } \\
\text { related factor }\end{array}$ & $\begin{array}{l}\text { The consultants should be } \\
\text { thorough and detailed with } \\
\text { the designs and ensured } \\
\text { adequate planning at design } \\
\text { stage. The consultants } \\
\text { should be mindful of skilled } \\
\text { manpower requirement of } \\
\text { the element. }\end{array}$ \\
\hline Upper floors & $\begin{array}{l}\text { Economic related factor, } \\
\text { contractor's related factor, } \\
\text { consultant's related } \\
\text { factor, workmanship's } \\
\text { related factor, client's } \\
\text { related factor, } \\
\text { technological related } \\
\text { factor. }\end{array}$ & 6 & $\begin{array}{l}\text { Contractor's related } \\
\text { factors, economic } \\
\text { related factor and } \\
\text { workmanship } \\
\text { related factor. }\end{array}$ & $\begin{array}{l}\text { Client's related } \\
\text { factor, } \\
\text { technological } \\
\text { related factor and } \\
\text { consultant's } \\
\text { related factor. }\end{array}$ & $\begin{array}{l}\text { The contractors' expertise } \\
\text { should be involved at design } \\
\text { stage in order to have in- } \\
\text { depth knowledge and } \\
\text { manpower requirement of } \\
\text { the element. Also, the } \\
\text { government should come out } \\
\text { with construction industry } \\
\text { friendly policies that would } \\
\text { reduce inflation among } \\
\text { others. }\end{array}$ \\
\hline Roof & $\begin{array}{l}\text { Client's related factor, } \\
\text { economic related factor, } \\
\text { consultant's related } \\
\text { factor, technological } \\
\text { related factor, } \\
\text { government's related } \\
\text { factor and workmanship's } \\
\text { related factor. }\end{array}$ & 7 & $\begin{array}{l}\text { Economic related } \\
\text { factor, client's } \\
\text { related factor and } \\
\text { technological } \\
\text { related factor } \\
\text { respectively }\end{array}$ & $\begin{array}{l}\text { Workmanship } \\
\text { related factor, } \\
\text { consultant's } \\
\text { related factor and } \\
\text { government } \\
\text { related factor } \\
\text { respectively }\end{array}$ & $\begin{array}{l}\text { The clients should be } \\
\text { adequately informed about } \\
\text { the cost, about the cost } \\
\text { requirements of the element } \\
\text { and likely fluctuation at } \\
\text { design stage. Also, the } \\
\text { designers should avoid } \\
\text { unnecessary complex designs } \\
\text { details with functional } \\
\text { characteristics.. }\end{array}$ \\
\hline
\end{tabular}

related factor, consultant's related factor, technological related factor, contractor's related factor, government related factor, and workmanship related factor, predispose roof to variation. Among these, three factors, that are, technological related factor, workmanship related factor, and economic related factor, are critical factors causing variation in substructure; two factors, that are, consultant related factor and workmanship related factor are critical factors causing variation in frame. Three factors, that is, contractor's related factor, economic related factor, and workmanship related factor are critical factors causing variation in upper floors and three factors, which are economic related factor, client's related factor, and technological related factor, are critical factors causing variation in roof.

The paper recommends that designers (architects and engineers) should undertake comprehensive assessment of building elements with respect to availability of technological and manpower requirement. Also the consultants should ensure that designs are thorough and detailed at the design stage to facilitate adequate planning while clients should be adequately informed of the cost requirements of the element and likely fluctuation at design stage. The contractors' expertise should, where procurement method permits, be involved at design 
stage in order to have in-depth knowledge and manpower requirement of the element. Also, the government should come out with construction industry friendly policies that would reduce inflation among others.

\section{References}

1. Chan, D.W.M. and Kumaraswamy, M.M., An Evaluation of Construction Time Performance in the Building Industry, Building and Environment, 31(6), 1996, pp. 569-578.

2. Harris and McCaffer, Construction Management, Macmillan Press Limited, London, 1998.

3. Hibberd, P.R., Variations in Construction Contracts, Collins, London, 1986.

4. Akinsola, A.O., Potts, K.F. and Ndekugri, I., Variations on Construction Projects: A Review of Empirical Studies, Building Research and Information, 22(5), 1994, pp. 269-271.

5. Ssegawa, J.K., Mfolwe, K.M., Makuke, B., and Kutua B., Construction Variations: A Scourge or a necessity?. [Online] Available at http://wwwbuildnet.csir.co.za/cdcproc/docs/3rd/ssegawa_jk_mfolwe_k m.pdf.2002, [Accessed on 4 January, 2010]

6. Mokhtar, A., Bedard, C., and Fazio, P., Collaborative Planning and Scheduling of Interrelated Design Changes, Journal of Architectural Engineering, ASCE, 6(2), 2000, pp. 66-75.

7. Arain, F.M., Assaf, S.A. and Low, S.P., Causes of Discrepancies between Design and Construction, Architectural Science Review, 47(3), 2004, pp. 237249.

8. Robert, P.C. and Harold, E.M., UNIFORMAT II Elemental Classification for Building Specifications, Cost Estimating, and Cost Analysis., [Online]. Available at http://www.bfrl.nist.gov/oae/publications/nistirs/6389.pdf. 1999. [Accessed on 4 January, 2010].

9. Arain, F.M., Potential Barriers in Management of Refurbishment Projects, Journal of Independent Studies and Research, 3, 2005, pp. 22-31.

10. Construction Industry Institute (CII), The Impact of Changes on Construction Cost and Schedule, Publication 6-10, Construction Industry Institute, University of Texas at Austin, TX. 1990.
11. Thomas, H.R. and Napolitan, C.L., The Effects of Changes on Labor Productivity: Why and How Much, CII Document 99, The Pennsylvania State University, USA, 1994.

12. Clough, R.H. and Sears, G.A., Construction Contracting, (6th edition) John Wiley \& Sons Inc., New York, 1994.

13. Fisk, E.R., Construction Project Administration, (5th edition) Prentice Hall, New Jersey, 1997.

14. Ibbs, C.W., Lee, S.A., and Li, M.I., Fast Tracking's Impact on Project Change, Project Management Journal, 29, 1998, pp. 35-41.

15. O’Brien, J.J., Construction Change Orders, McGraw Hill, New York, 1998.

16. Mokhtar, A., Bedard, C., and Fazio, P., Collaborative Planning and Scheduling of Interrelated Design Changes, Journal of Architectural Engineering, ASCE, 6(2), 2000, pp. 66-75.

17. Gray, C. and Hughes, W., Building Design Management, Butterworth-Heinemann, Oxford, United Kingdom, 2001.

18. Arain, F.M., Assaf, S.A. and Low, S.P., Causes of Discrepancies between Design and Construction, Architectural Science Review, 47(3), 2004, pp. 237-249.

19. Aibinu, A.A. and Jagboro, G.O., The Effects of Construction Delays on Project Delivery in Nigerian Construction Industry, International Journal of Project Management, 20(8), 2002, pp. 593-599.

20. Ikpo, I.J., Variability Analysis of Prime Cost Sums, Civil Engineering Dimension, 10(1), 2008, pp. 4044.

21. Ogunsemi, D.R. and Jagboro, G.O., Time-Cost Model for Building Projects in Nigeria, Construction Management and Economics, 24(3), 2006, pp. 253-258.

22. Proverbs, D.G., Holt, G.D., and Olomolaiye, P.O., Productivity Rates and Construction Methods for High Rise Concrete Construction: A Comparative Evaluation of UK, German and French Contractors, Construction Management and Economics, 17(1), 1999, pp. 45-52.

23. Awakul, P. and Ogunlana, S.O., The Effect of Attitudinal Differences on Interface Conflicts in Large Scale Construction Projects: A Case Study, Construction Management and Economics, 20(4), 2002, pp. 365-377.

24. Field, A.P., Discovering Statistics Using SPSS, ( $2^{\text {nd }}$ edition) Sage, London, 2005. 